\title{
Identification of Land Suitability for Agricultural Use by Applying Morphometric and Risk Parameters Based on GIS Spatial Analysis
}

\author{
Ştefan BILAŞCO ${ }^{1,2 *}$, Sanda ROŞCA ${ }^{1}$, Ioan PĂCURAR ${ }^{3}$, \\ Nicolaie MOLDOVAN ${ }^{3}$, Amalia BOȚ ${ }^{3}$, Cornel NEGRUȘIER ${ }^{3}$, \\ Paul SESTRAS ${ }^{4}$, Mircea BONDREA ${ }^{5}$, Sanda NAȘ ${ }^{5}$
}

\author{
I"Babes-Bolyai"University, Faculty ofGeography, 400006Chij-Napoca, Romania;sbilasco@geografie.ubbchij.ro (correspondingauthor);sanda.rosca@geografie.ubbchy.ro \\ ${ }^{2}$ Romanian Academy, Cliy-Napoca Subsidiary Geography Section, 9Republicii Street, \\ 400015 Chij-Napoca, Romania \\ ${ }^{3}$ University of Agricultural Science and Veterinary Medicine, 3-5 ManasturSt, 400372 Clij-Napoca, \\ Romania;moldovan.nicolaie@gmail.com;ioanpacuranj@yahoo.com;bot.amaliaioana@gmail.com; comelnegrusien@gmail.com \\ ${ }^{4}$ University of Agronomic Sciences and VeterinaryMedicine Bucharest,59MäraşstiBlvd, District 1,01 1464, Bucharest Romania;paulsestras@usamv.ro \\ ${ }^{5}$ Technical University of Chij-Napoca, Faculty of CivilEngineering, Department of TerrestrialMeasurement and Cadastre, 25 G. Baritiu St., 400027 Chij-Napoca, \\ Romania;mirce_bondrea@yahoo.com;sandanas@mtcutclyj.ro
}

\begin{abstract}
Agricultural land is one of the main resources for the development of rural communities and the peripheries of urban centres. An area of $936 \mathrm{~km}^{2}$, belonging to Intercommunity Association for Development Alba-Iulia, Transylvania region, Romania, was analysed in order to identify suitable land for agricultural use. This approach represents the stage preceding the identification of crops favourability for agricultural land, thus reducing the time and resources needed for the proper land evaluation mark. The extension of suitable surfaces for agricultural crops was realized using a GIS model based on spatial analysis, taking into account morphometric parameters (slope, altitude, slope orientation, the density of fragmentation) and the risk factors (probability of landslides, flooding, temperature and rainfall). The outcome of the case study was an agricultural land suitability map of the investigated area, which provides valuable information regarding areas suitable for crops. By applying this model, a better management of agricultural lands can be assured, representing an alternative to the classic method of evaluation marks. The proposed model was validated by comparing the results with the grades of crop suitability, method achieved through the land evaluation mark.
\end{abstract}

Keywords: agricultural land, database, favourable crops, GIS model, maps

\section{Introduction}

Agricultural land, as a support for the economic development of rural areas and the peripheries of urban major centres, represents even today a major interest for an efficient management of cultivable land, in terms of implemented crops. Sustainable agriculture relies on the use of land parcels, taking into account the specifics and their own production capacity (FAO, 1983). In the centre of Romania, Transylvania region, Intercommunity Association for Development Alba-Iulia (IADA) includes mainly rural areas, where the major activity is linked to land use. The economic profile of rural areas delimited by IADA is based on agricultural activities of land cultivation, having as main sales market the polarizing urban centres.

The GIS model shown in the present article was intended to facilitate the agricultural land evaluation mark; the main purpose of was to reduce the time provided for the identification of favourability for some agricultural crops by imposing restrictiveness among the territory involved in the research. Using GIS technology with the purpose of identifying these territories has provided remarkable results for land evaluation mark (Dumitru et al., 2010; Bhandari et al., 2013; Halder, 2013; Roşca et al., 2015).

Achieving the spatial analysis model relies on the morphometric and risk parameters of the studied territory, parameters that have the greatest influence on land suitability and on the arrangement of different types of crops. 


\section{Materials and Methods}

\section{Studied area}

Intercommunity Association for Development Alba Iulia has 11 territorial administrative units (Fig. 1), spread over $936 \mathrm{~km}^{2}$, which corresponds to $14.9 \%$ of the total area of Alba County, Romania(IADA, 2009).

Land use of the terrain within the analysed area is mainly agricultural, of which agricultural land occupies a share of 31\% from the total surface, followed by pastures (Moldovan et al., 2015).

Agricultural production and crop type applied to different territories are under the direct influence of the environment and in recent years under the influence of anthropogenic factors, that may mitigate or exacerbate the restrictive nature or favourability of a territory. Thereby, the territory was identified by the main morphometric and morphographic characteristics related to the major relief units from the analysed area, with direct and indirect influence on favourability and restrictive aspects of the analysed area for different use of land, as a result of the conditions imposed by altitude, slope, fragmentation depth, fragmentation density, slope exposure etc.

\section{Theoretical aspects}

The parameters taken into account (slope, altitude, slope orientation, fragmentation depth, fragmentation density, temperature, rainfalls, probability of landslides) were analysed in

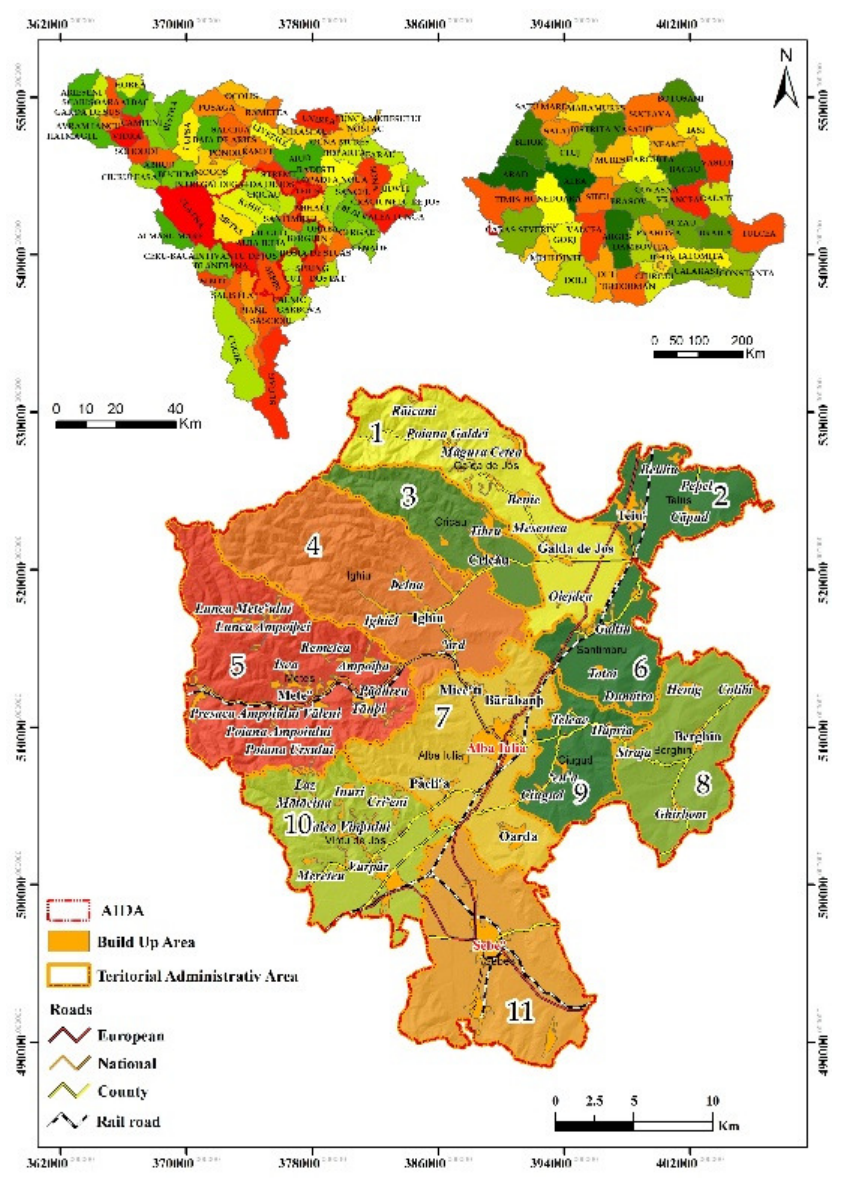

Fig. 1. Geographical position of the analysed territory terms of their favourability influence on the following crops: potato, wheat, vegetables, lucerne, peas, barley, corn, clover, based on the methodology for land evaluation mark for agricultural lands (Teaci et al., 1972, 1989; Cernescu et al., 1986, 1989; Munteanu et al., 2000; Ţârău, 2003; Păcurar and Buta, 2007; Roşca, 2014). Previous studies highlighted superior results obtained in terms of spatial distribution of land suitability for certain crops based on GIS modelling, if the chosen factors involved in the modelling are consistent with the land (Van Diepen et al., 1991).

Slope

Slope is a characteristic parameter of the relief which has an influence on production capacity of the agricultural land and also on the technological classification of the analysed territory. The influence of this parameter is reflected on the agricultural land both in terms of land degradation (Moțoc, 1983), mainly because of the erosion processes on surfaces with high slope and accumulation of material eroded on surfaces with sudden change of slope, and also in terms of mechanization of these lands, because plowing and cultivating on steep slopes is difficult for mechanized systems.

In terms of regional spatial distribution of areas with different degrees of inclination of the land, on IADA territory stands out moderate level of inclined slopes with a share of $30.40 \%$ of the total. Territorial areas characterized by slopes from $0.01 \%$ to $10 \%$ included in horizontal to slightly inclined categories, represented $38 \%$ of the total (Table 1 ).

Categories high, very high and steep slope, assigned to a variation greater than $25 \%$ represented approximately $31 \%$ of the total territory analysed. Based on the surface analysis of slope groups, stands out the large share of groups classified as suitable slopes to agricultural use, which highlights the agricultural suitability in terms of the slope of the analysed territory. Identifying the categories of territorial spatial gradient highlights the engraftment of slopes suitable for agricultural use on lower area of Mures, corridor and on mollify slopes of lower hills (Fig. 2). Surfaces with high slope, very high and steep are located mostly at the contact between mountain area, located at the Northwest border of the analysed area, as well at the contact area between the large meadow of Mures and the foothills (Fig. 2). This final aspect introduces restrictiveness on agricultural land suitability both in terms of agricultural crops and mechanized work.

\section{Altitude}

Levelling the relief on altitudinal steps has an indirect influence on the surface arrangement of agricultural lands, inducing restrictiveness through the components. The main two components that need to be analysed consistent with relief in terms of restrictiveness which they impose for the identification and spatial disposition of agricultural lands are temperature and

Table 1. The distribution of slope classes for the studied area

\begin{tabular}{lccc}
\hline \multirow{2}{*}{ Slope groups (\%) } & \multirow{2}{*}{ Type } & $\left(\mathrm{Km}^{2}\right)$ & $\%$ \\
\cline { 3 - 4 } & & 85.90 & 9.66 \\
\hline 2 & Horizontal & 157.21 & 17.68 \\
$5.1-5$ & Very low & 108.66 & 12.22 \\
$10.1-25$ & Low & 270.38 & 30.40 \\
$25.1-50$ & Moderate & 220.32 & 24.77 \\
$50.1-100$ & High & 46.77 & 5.26 \\
$>100$ & Very high & 0.13 & 0.01 \\
\hline
\end{tabular}


304

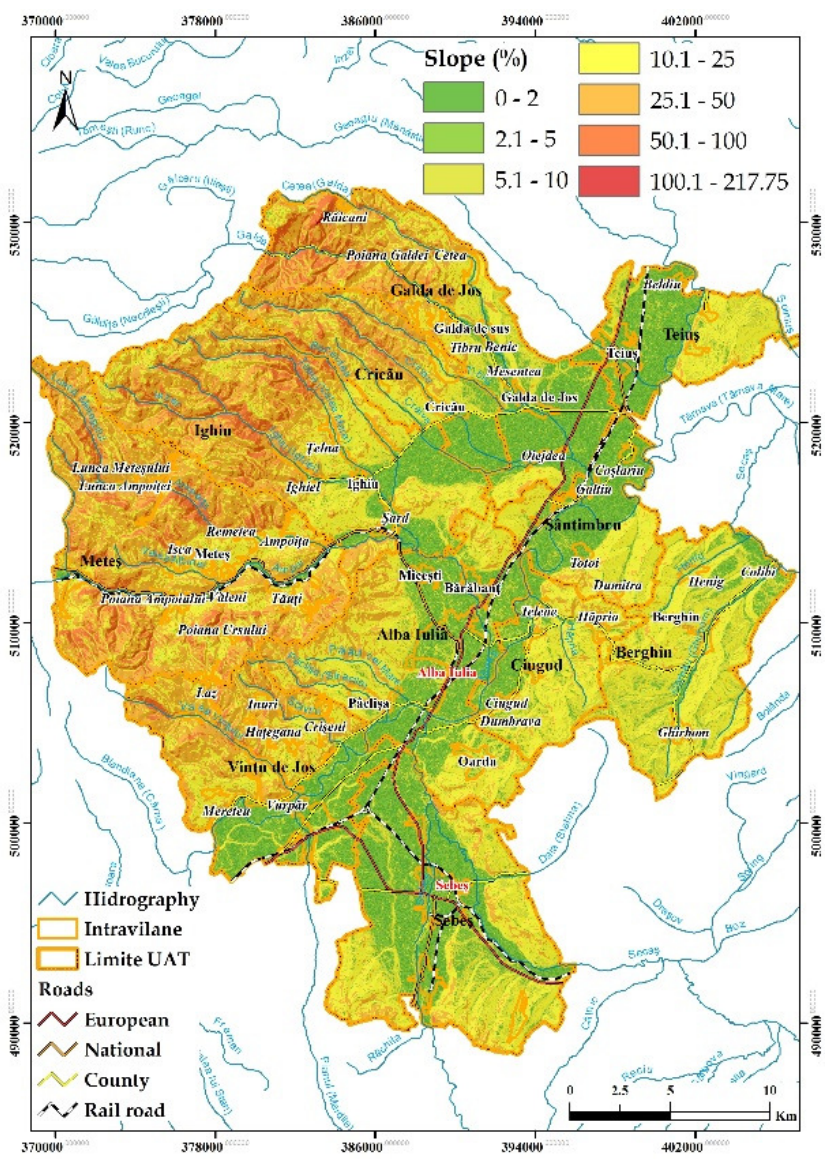

Fig. 2. Slope map

rainfall, regarded as elements of risk because of their unpredictability manifestation on relief units. The altitudinal difference that fall within the analysed territory was $1,085 \mathrm{~m}$, from an altitude of $1,250 \mathrm{~m}$ on the Eastern versant of Bedeleu Peak, to $165 \mathrm{~m}$ on the Mureș river meadow. This high altitudinal difference revealed the complexity of the analysed territory, given not only by the altitude of the relief, but also by the complexity of the hydro-climatic factors, lithological and pedological characteristics.

In terms of territorial extension, stand out the surfaces with altitudes up to $500 \mathrm{~m}$ in proportion of $70.61 \%$ of the analysed surface, which highlight a relatively high suitability of lands reported at altitudes (Fig. 3). The favourability for agricultural crops and the rural/urban development and ways of communications was represented for Mures Valley in the analysed territory by Abrud (North sector) corridor and Vintu corridor, where the altitudes of the intervals $201-250 \mathrm{~m}$ and $251-500 \mathrm{~m}$ (Table 2) represented low hills and extended meadows that provide the necessary conditions for de development of the region.

Table 2. The distribution of altitudinal classes for the studied area

\begin{tabular}{cccc}
\hline \multirow{2}{*}{$\begin{array}{c}\text { Altitudinal } \\
\text { classes }(\mathrm{m})\end{array}$} & Characteristic landforms & \multicolumn{2}{c}{ Surface } \\
\cline { 3 - 4 } & & $\left(\mathrm{Km}^{2}\right)$ & $\%$ \\
\hline $165-200$ & Terraces, meadows & 180.17 & 20.26 \\
$201-500$ & Low and medium hills & 447.81 & 50.35 \\
$501-750$ & High hills & 133.83 & 15.05 \\
$751-1000$ & Very high hills & 93.88 & 10.56 \\
$1001-1250$ & Mountains with low altitude & 33.69 & 3.79 \\
\hline
\end{tabular}

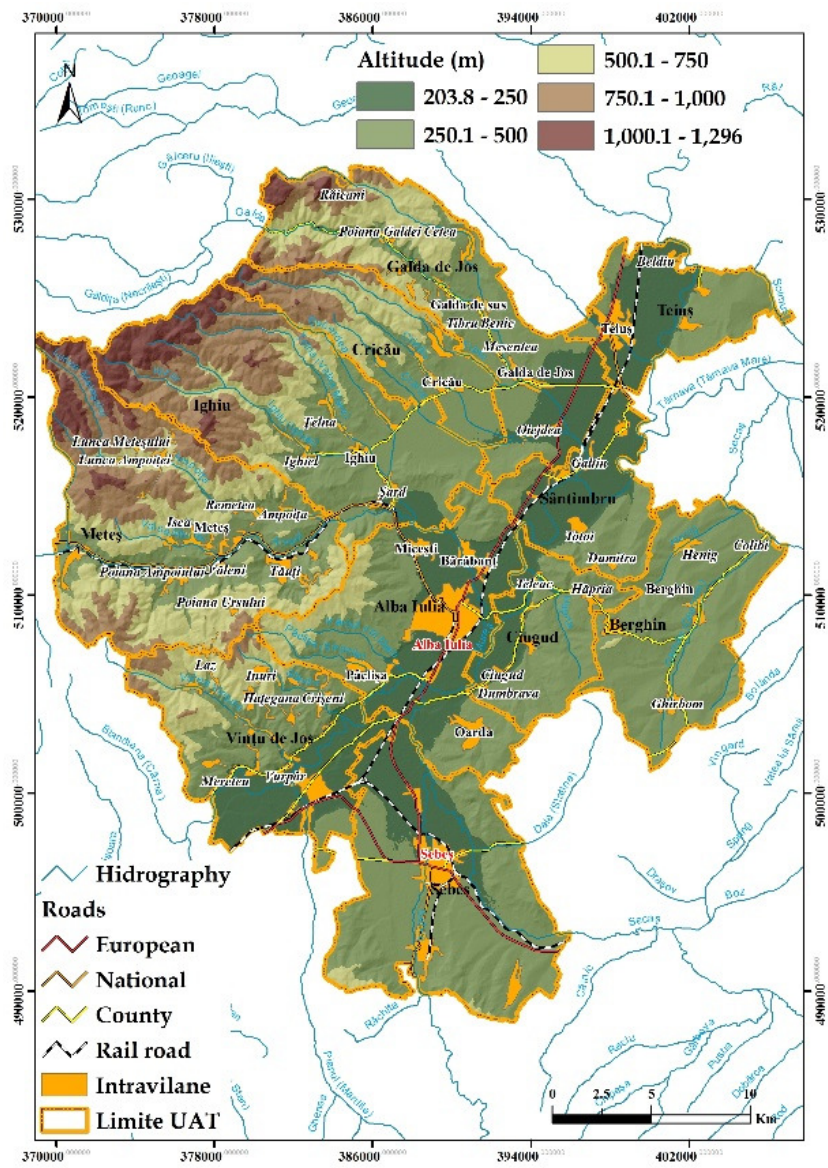

Fig. 3. Hypsometric map

\section{Slope orientation}

Slope orientation, as a parameter used in land evaluation mark, provides information related to the exposure to the sun and wind, probably wet areas and areas with lack of humidity. The analysis of orientation provides indirect information on hydric and thermal regime of micro-regions; thus Southern slopes have higher temperatures, therefore are characterized by moderate humidity, while Northern slopes have lower temperatures and are shady, resulting in a higher humidity. Also, thermic oscillations are higher on Southern slopes compared to those in the North. By the direct action of thermic difference, humidity and specialized studies, versants with Southern and Northern exposure are highly affected by erosion processes (Motoc, 1983). Their share was $12.86 \%$ for versants with Southern orientation and $9.80 \%$ for those with Western orientation, standing out in terms of percentage of sunny slopes (33\%) and half sunny (23\%) (Fig. 4, Table 3).

Table 3. The distribution of slope exposure classes for the studied area

\begin{tabular}{llcc}
\hline \multirow{2}{*}{ Slope exposure } & \multirow{2}{*}{ Exposure } & \multicolumn{2}{c}{ Surface } \\
\cline { 3 - 4 } & \multirow{2}{*}{ Shady } & 110.12 & 12.39 \\
\hline $\mathrm{N}$ & & 131.29 & 14.76 \\
$\mathrm{NE}$ & \multirow{2}{*}{ Half-shady } & 127.83 & 14.37 \\
$\mathrm{E}$ & 93.37 & 10.49 \\
$\mathrm{NW}$ & & 114.45 & 12.86 \\
$\mathrm{~S}$ & \multirow{2}{*}{ Sunny } & 99.70 & 11.21 \\
SW & & 87.16 & 9.80 \\
W & \multirow{2}{*}{ Half-sunny } & 123.73 & 13.91 \\
SE & & & \\
\hline
\end{tabular}




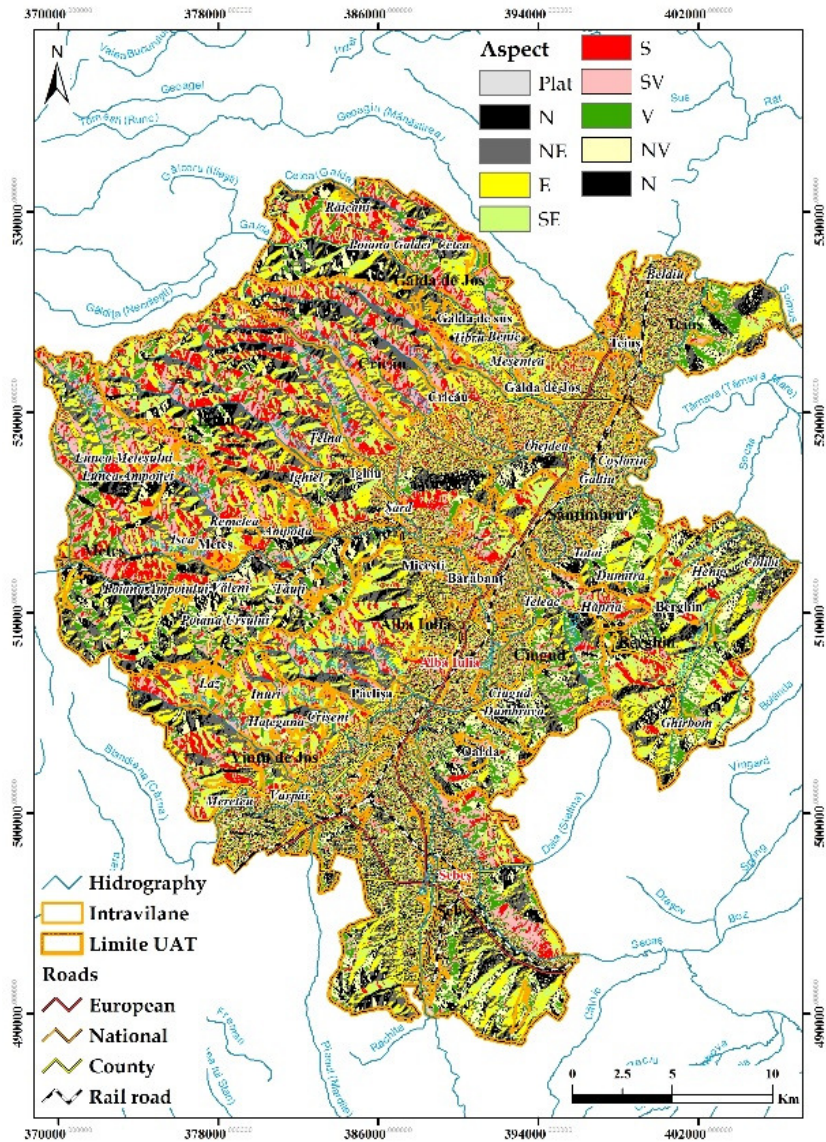

Fig. 4. Slope orientation map

Due to the high degree of sunlight, the versants with Southern and South-eastern exposure, lead to a more rapid melting of the snow during March-April. These are preponderant developed in right sub-basins and, in a lesser extent, in left sub-basins.

Thus, this characteristic can be managed locally by adapting forest and agricultural arrangements, but also by correct location and proper management of the operation and construction of communication lines.

\section{Fragmentation depth}

Fragmentation depth represents the depth of local basins of erosion (Grigore, 1973), providing useful preliminary information in the current study about the morphological potential and favourability or restrictiveness of transport infrastructure development. Values of this indicator ranged between 4.43 and $511.6 \mathrm{~m} / \mathrm{km}^{2}$, with an average at basin level of $147 \mathrm{~m} / \mathrm{km}^{2}$. Values higher than $300 \mathrm{~m} / \mathrm{km}^{2}$ correspond to steep slopes from the mountain area, occupying $33 \%$ of the territory, the difference of 50 up to $300 \mathrm{~m} / \mathrm{km}^{2}$ being found in the interfluvial areas, with higher altitudes, occupying $20 \%$ of the territory (Table 4). These territories need a special attention both for cultivation and achieving works, as well as for transport. Territories with low values of relief energy are favourable for crops, promoting mechanization and easy access to the parcels, establishing large parts in the category of territories favourable for agricultural land use (Fig. 5). Analysing the spatial representation of this indicator, there can be noticed a pronounced character of right asymmetry: the Western sector of the analysed territory featuring values that can reach up to 500

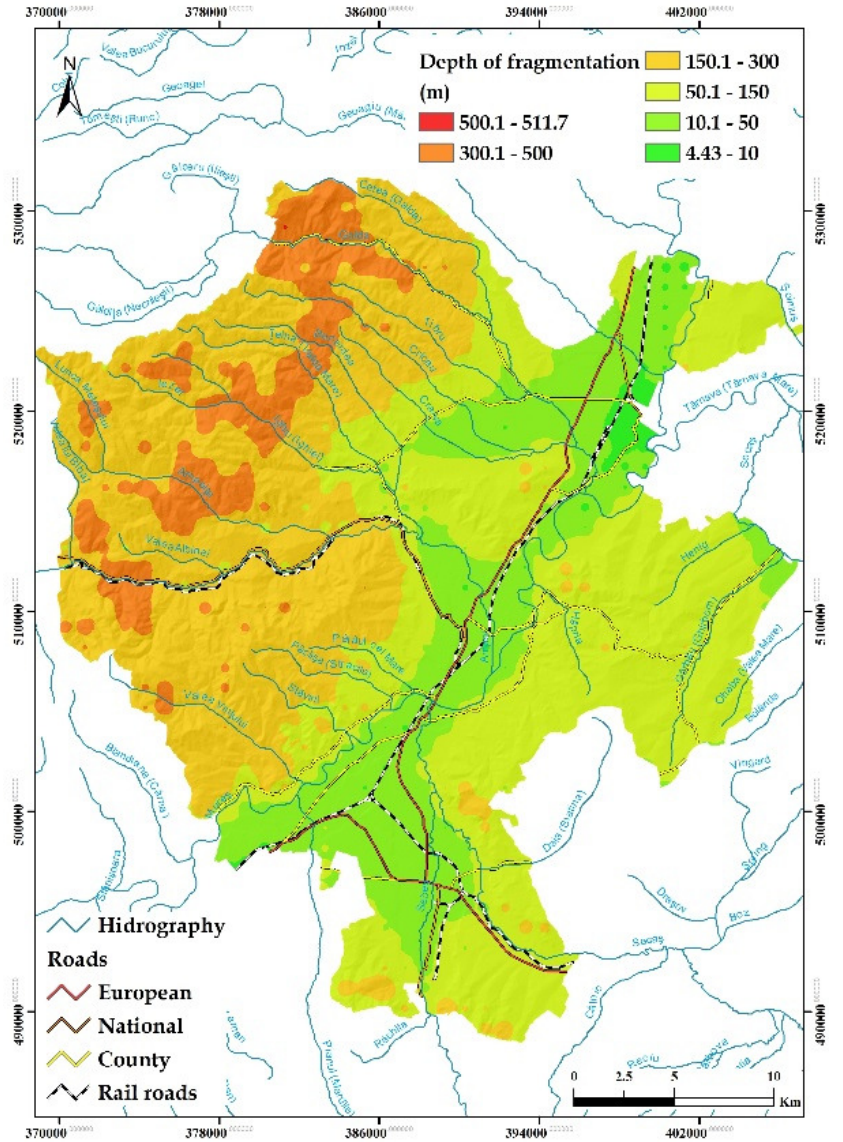

Fig. 5. Fragmentation depth map

Table 4. The distribution on fragmentation depth classes for studied area

\begin{tabular}{lcc}
\hline \multirow{2}{*}{ Relief energy $(\mathrm{m})$} & \multicolumn{2}{c}{ Surface } \\
\cline { 2 - 3 } & $\mathrm{km}^{2}$ & $\%$ \\
\hline$<10$ & 83.65 & 8.92 \\
$10.1-50$ & 341.76 & 36.47 \\
$50.1-150$ & 188.26 & 20.09 \\
$150.1-300$ & 0.03 & 0.003 \\
$300.1-500$ & 314.01 & 33.51 \\
$500.1-511.7$ & 9.21 & 0.98 \\
\hline
\end{tabular}

$\mathrm{m} / \mathrm{km}^{2}$ in comparison with the Eastern sector which has high values only in the South-Eastern sector, that corresponds with interfluves surfaces. This regionalization derives from the structural and neotectonic conditions on river erosion that is to be found in the analysis of drainage density.

\section{Drainage density}

The drainage density, calculated as the ratio between permanent and temporary hydrological network length $(\mathrm{km})$ to surface analysed territory $\left(\mathrm{km}^{2}\right)$, indicated an average value of $0.82 \mathrm{~km} / \mathrm{km}^{2}$, with variations between 0 and $6.2 \mathrm{~km} / \mathrm{km}^{2}$. The interval of $0-0.5$, with a share of $29.35 \%$ of the territory correspond to the superior sectors of mountainsides, followed, in percentage terms, by the intervals $0.5-1$ and 1.1-2 with approximately equal weightings (of 34\%), characterizing the principal tributaries meadows of Mures and the middle section of low hills (Fig. 6, Table 5). The values of this parameter will produce valuable information on the drainage capacity of the territory, along with the slope, permeability and groundwater depth. 


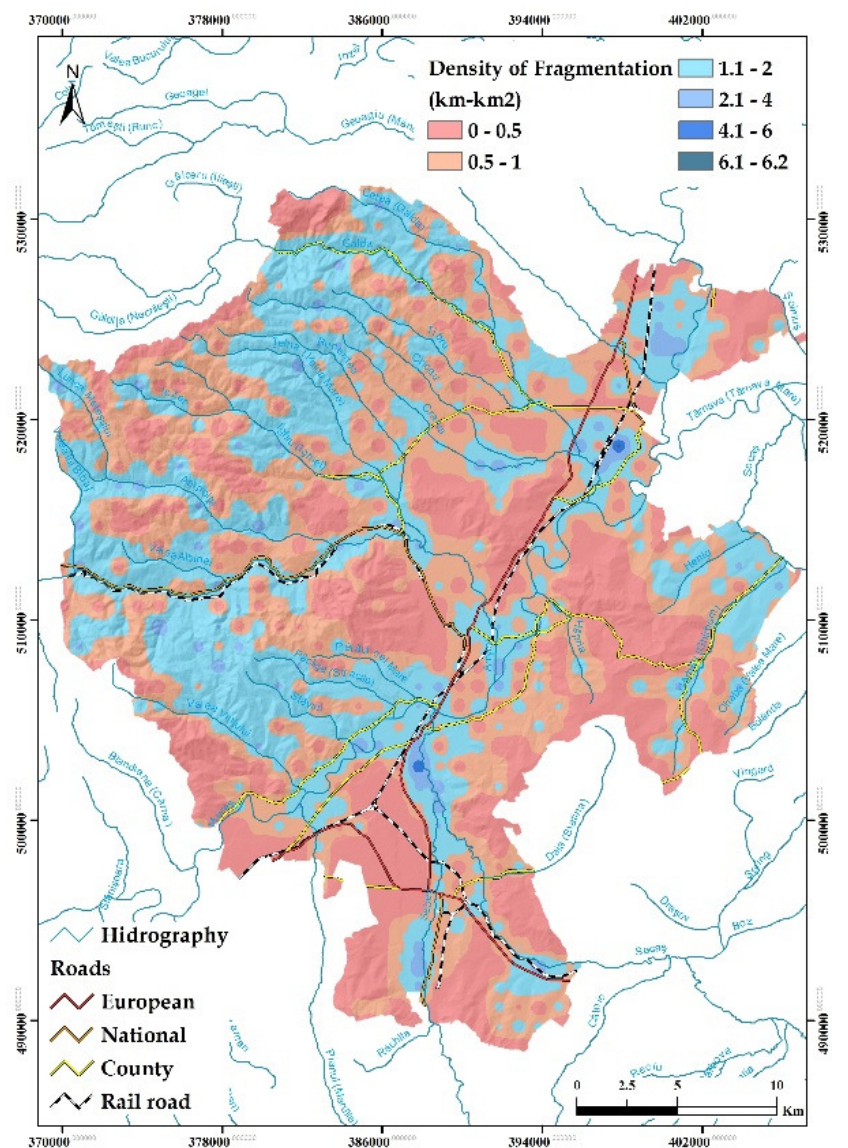

Fig. 6. Fragmentation density map

Table 5. The distribution on drainage density classes for analysed territory

\begin{tabular}{lcc}
\hline \multirow{2}{*}{ Drainage density } & \multicolumn{2}{c}{ Surface } \\
\cline { 2 - 3 } & $\mathrm{Km}^{2}$ & $\%$ \\
\hline $0-0.5$ & 275.08 & 29.35 \\
$0.5-1$ & 321.80 & 34.34 \\
$1.1-2$ & 319.85 & 34.13 \\
$2.1-4$ & 19.83 & 2.12 \\
$4.1-6$ & 0.58 & 0.06 \\
$6.1-6.2$ & 0.02 & 0.00 \\
\hline
\end{tabular}

\section{Temperature}

The peculiarities of relief by altitude, orientation and fragmentation, give the variation of hydro-climatic parameters. Given the integrated nature of the present study, in order to identify the correct distribution of rainfall and average temperatures, databases were obtained on average annual temperatures and multiannual average rainfall, throughout statistical spatial analysis of measured point values.

In order to obtain the value of average rainfall of the studied territory, the Digital Elevation Model (DEM) was used as well as the average amount of rainfall (Bilașco, 2010) from the weather stations. The results of specialized studies conducted in Romania allowed framing the analysed territory according to classes of average annual temperatures (Table 5). The analysed results

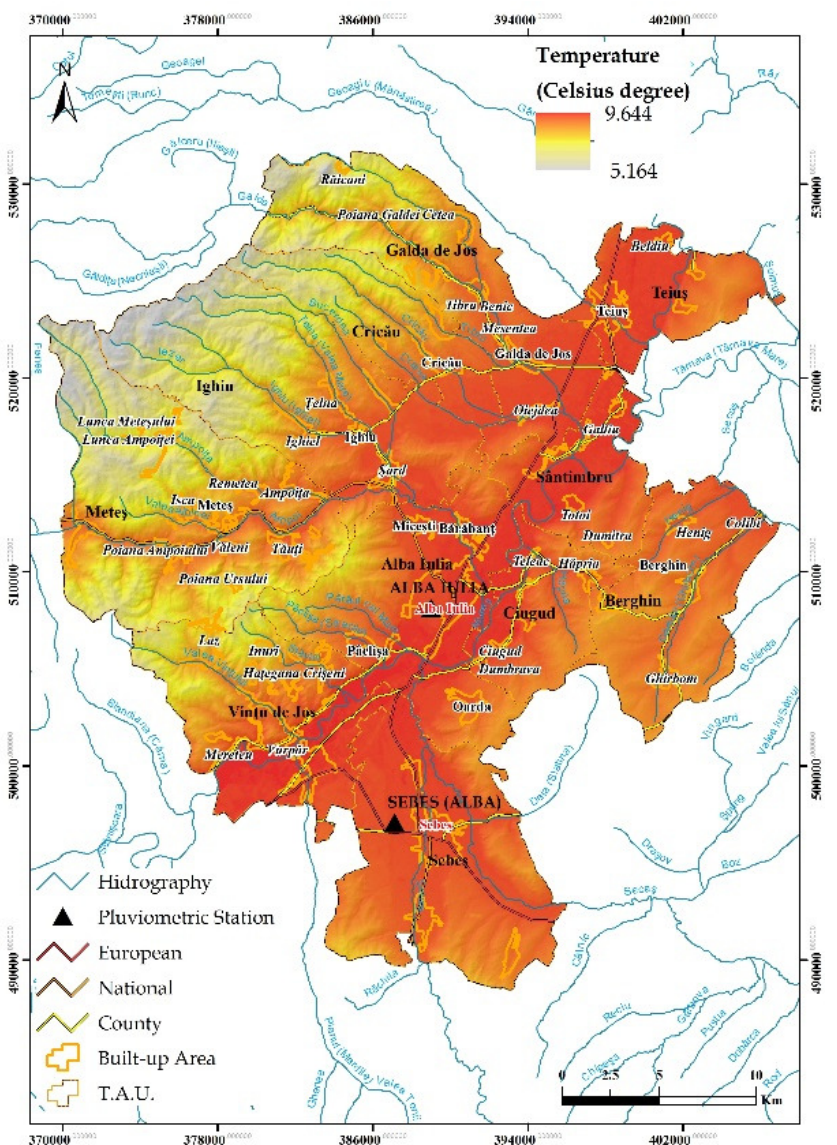

Fig. 7. The distribution of the annual average temperature

Table 6. The distribution of annual average temperature classes for the studied area

\begin{tabular}{cccc}
\hline $\begin{array}{c}\text { Annual average } \\
\text { temperature } \\
\left({ }^{\circ} \text { Celsius }\right)\end{array}$ & $\begin{array}{c}\text { Temperature } \\
\text { classes }\end{array}$ & $\left(\mathrm{km}^{2}\right)$ & $\%$ \\
\hline $5.6-6$ & Below average & 19.5 & 2.03 \\
$6.1-7$ & Medium & 207 & 22.03 \\
$7.1-8$ & High & 711 & 75.93 \\
$8.1-9$ & & & \\
$9.1-9.64$ & & & \\
\hline
\end{tabular}

clearly highlighted the temperature variation with altitude, the highest temperatures representing areas of Mures corridor, part of the submontane hills and low hills (Fig. 7).

\section{Rainfall}

The rainfall parameter directly affects the agricultural crop arrangement specific for agricultural land due to variation in the quantity of water in a certain range. Water reserve is closely related to temperature and tightly correlated with the amount of water precipitated in a period of time. The influence of rainfall stands out by their natural setting on altitude, sub medium values for modeled precipitation in the low area of corridor and medium amounts of precipitation for the foothills and mountain area related to IADA (Fig. 8). The largest area of rainfall in 


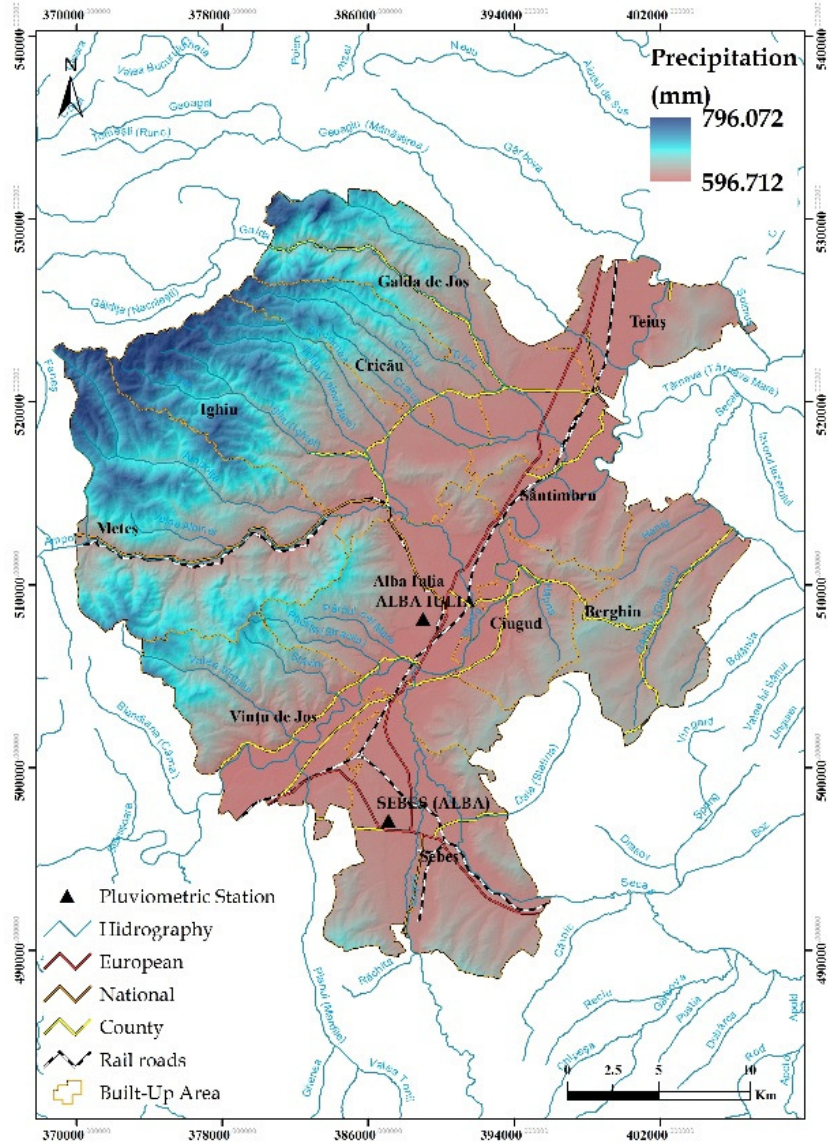

Fig. 8. The distribution of annual average rainfall

Table 7. The distribution of the annual rainfall classes

\begin{tabular}{llll}
\hline \multirow{2}{*}{$\begin{array}{c}\text { Average precipitation } \\
(\mathrm{mm})\end{array}$} & \multirow{2}{*}{$\begin{array}{c}\text { Precipitation } \\
\text { classes }\end{array}$} & \multicolumn{2}{c}{ Surface } \\
\cline { 4 - 4 } & Below & $\left(\mathrm{km}^{2}\right)$ & $\%$ \\
\hline $596-600$ & medium & 0.12 & 0.013 \\
$601-700$ & Medium & 933.88 & 99.98 \\
$701-796$ & & & \\
\hline
\end{tabular}

proportion of $99.98 \%$ falls in the middle category, regarding favorability (Table 7). This highlights a good favorability in terms of agricultural crops category because there is a good reserve of water for most of the territory. Areas with deficient rainfall and thus little water reserve from precipitations ensure water reserve from the phreatic water near the surface of Mures meadow.

\section{Landslides}

The analysed territory, located predominantly in Western Transylvania Depression as a result of geographical and geological characteristics, have a high potential for landslides occurrence (Petrea et al., 2015), and strong dynamic and accelerating trend of sliding because of cumulative rainfall triggering landslides (Roșca et al., 2015).

After applying the bivariate statistical analysis model, the probability of occurrence of landslides was obtained based on the analysis of causative and triggering factors from the administrative territorial units of IADA (Moldovan et al., 2015) (Fig. 9). Most landslides occur in areas with geology dominated

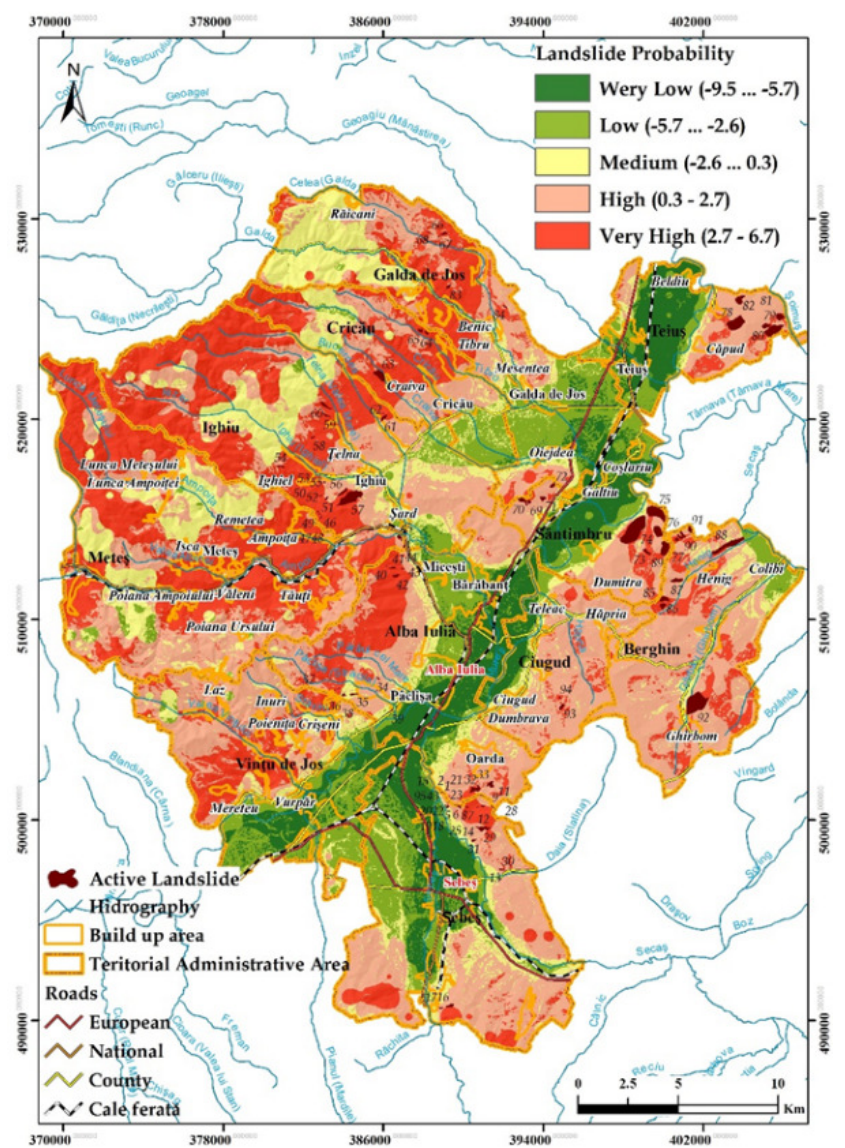

Fig. 9. Probability of landslides occurrence map

Table 8 . The distribution of probability classes for landslide occurrence

\begin{tabular}{lcc}
\hline \multirow{2}{*}{ Landslide probability } & \multicolumn{2}{c}{ Surface } \\
\cline { 2 - 3 } & $\left(\mathrm{km}^{2}\right)$ & $\%$ \\
\hline Very Low $(-9.5 \ldots-5.7)$ & 96.1236 & 10 \\
Low $(-5.7 \ldots-2.6)$ & 116.0904 & 12 \\
Medium $(-2.6 \ldots 0.3)$ & 147.4788 & 16 \\
High $(0.3-2.7)$ & 333.7196 & 36 \\
Very High $(2.7-6.7)$ & 242.14 & 26 \\
\hline
\end{tabular}

by gravels, sands, clays, coal, sandy marl, conglomerates, sandstones, clays and purple striped marl. In the category of morphometric characteristics there was a high density of landslides on moderately inclined slope class (10.1-25.0\%) on the territories characterized by an energy relief within 50.1-150 and 150.1-300 $\mathrm{m}$ and a fragmentation density between 0.5-1, with West and North-West orientation (Table 8). Landslides through areas with different degrees of vulnerability are one of the main restrictiveness factors of land cultivation. Major restrictions are induced on surfaces included in high and very high vulnerability due to the instability of the respective areas.

\section{Flooding}

Flooding classes identified in the analysed territory lead to its inclusion in two classes: unflooded and rarely flooded (Fig. 10). The two classes have been obtained by identifying the corresponding maximum flow of flood levels with the probability of occurrence of $1 \%$, whose correspondent level has been transposed on transverse profiles (Roșca et al., 2014b; 
308

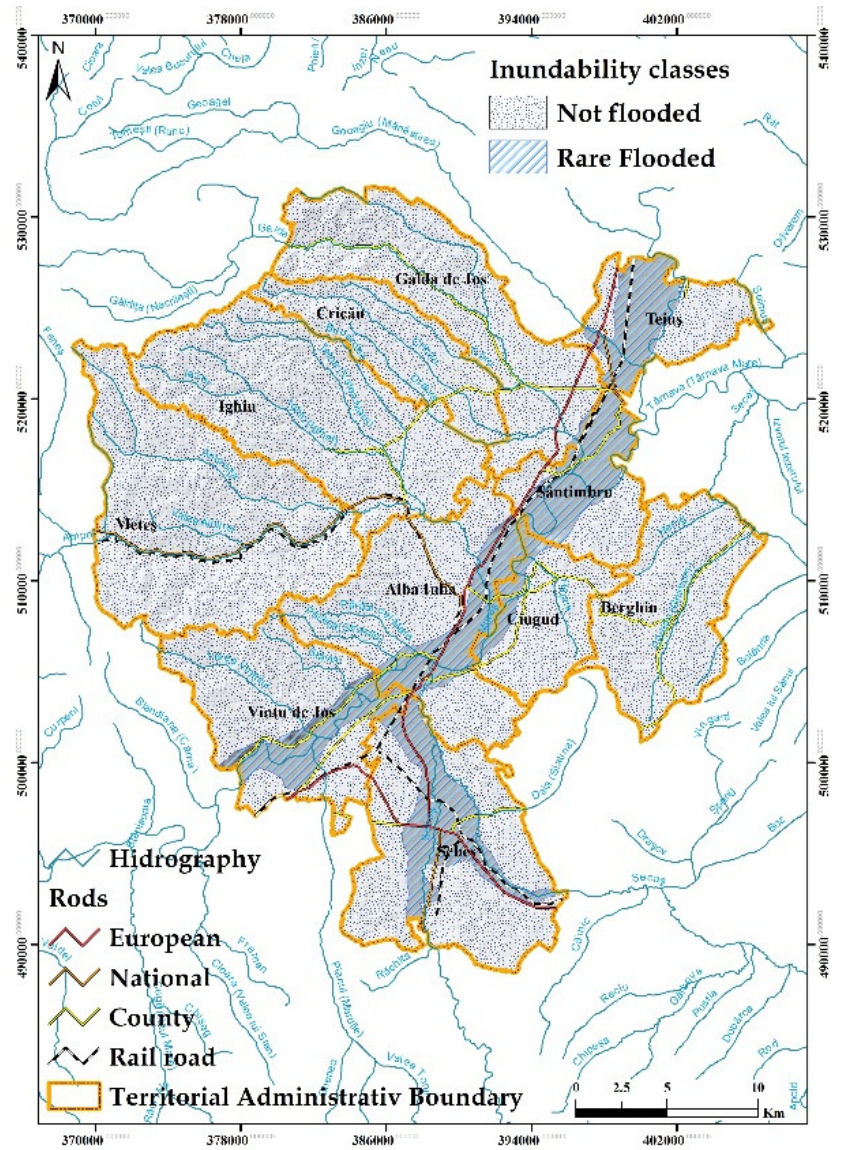

Fig. 10. Map of flooding classes

Table 9. The distribution of flooding classes

\begin{tabular}{lcc}
\hline \multirow{2}{*}{ Flooding } & \multicolumn{2}{c}{ Surface } \\
\cline { 2 - 3 } & $\left(\mathrm{km}^{2}\right)$ & $(\%)$ \\
\hline Flooded & 127 & 13.5 \\
Unflooded & 810 & 86.5 \\
\hline
\end{tabular}

Bilaşco and Bătinaş, 2009). Most of the territory $\left(810 \mathrm{~km}^{2}\right)$ is represented by the unflooded territories, while the rest of 127 $\mathrm{km}^{2}$ being represented by territories that present a probability of flood occurrence associated with a return period of once in a hundred years (Table 9). Inundability is one of the restrictive factors in terms of identifying areas suitable to any type of crops. Areas included into the flooding category have very high restrictiveness, going up to smaller restrictiveness or even zero where territories are not included in any flooding category.

\section{GIS model for land suitability to agricultural crops}

Agricultural crop land modelling suitability was based on the analysis of the parameters presented above, parameters embedded in a logic model of integrated spatial analysis. The pattern was defined in such a way that it could capture the influence of each analysed factor (7 factors), the final result revealing the areas suitable for agricultural crops.

The suitability model was developed on specific databases for each parameter included in the spatial analysis methodology based on their integration equations.

\section{Database and methodology}

Each of the indicators mentioned above were integrated into a database that contains primary, derived and modelled layers with their distribution in the analysed hydrographic basin (Table 10).

Each element of the database was included in the spatial analysis model, focusing on identifying areas suitable for agricultural crops for each parameter (Roşca et al., 2015). Using information extracted from the analysis stage of morphometric parameters, there were identified quantitative values that define areas suitable for each parameter (Table 11), values used in the spatial analysis.

Spatial analysis for identifying areas suitable for agricultural crops is based on overlay technique of identifying unique areas, which requires integrated analysis of the technical parameters included in the model based on equations of spatial analysis (Roşca et al., 2015), for highlighting any areas that meet both conditions (Fig. 11).

The spatial analysis was divided into three distinct methodological steps, each playing an important role in the final output. The first step was achieving specific databases which were derived from pre-existing databases, raster database (slope, altitude, aspect). Sub models are present in the model due to the fact that it is necessary to correct temperature and rainfall that were performed as secondary model through exploitation of raster modelled databases (temperature and rainfall), the primary (DEM) and derivatives (slope, orientation). In order to obtain density and fragmentation depth parameters of relief, the overlay technique was used on raster vector structures (surfaces of $1 \mathrm{~km}^{2}$ and DEM) and vector structures (surfaces of $1 \mathrm{~km}^{2}$ and the hydrographic network as primary data vector).

The second stage consisted in analysing the databases representing the input parameters in the model to spatial identify each influence and thus the areas suitable for crops. Also, in this stage, the minimum and maximal quantity limits have been set on variation of suitability for each parameter, as well as the identifier used.

Table 10. Database structure

\begin{tabular}{|c|c|c|c|c|}
\hline Nr. & Database & Structure type & Source/resolution & Database type \\
\hline 1. & DEM & Raster (grid) & $20 \mathrm{~m}$ & primary \\
\hline 2. & Hydrography & Vector & Topographical Maps & primary \\
\hline 3. & Inundability & Raster (grid) & $1 \%$ modelled flood stripes & modelled \\
\hline 4. & Slope & Raster (grid) & degrees & derived \\
\hline 5. & Orientation & Raster (grid) & Derived from DEM & derived \\
\hline 6. & Drainage density & Raster (grid) & $\mathrm{m} / \mathrm{km}^{2}$ & modelled \\
\hline 7. & Depth & Raster (grid) & $\mathrm{m}$ & modelled \\
\hline 8. & Precipitation data & Raster (grid) & Interpolation with a statistical model & modelled \\
\hline 9. & Temperature data & Raster (grid) & Interpolation with a statistical model & modelled \\
\hline 10. & Landslide areas & Raster (grid) & BSA model & modelled \\
\hline 11. & Suitability & Raster (grid) & $20 \mathrm{~m}$ & modelled \\
\hline
\end{tabular}


Table 11. Parameters used in modelling

\begin{tabular}{|c|c|c|c|c|c|}
\hline $\mathrm{Nr}$. & Parameters & Values & $\begin{array}{l}\text { Veryhigh suitability } \\
\text { (1) }\end{array}$ & $\begin{array}{c}\text { High suitability } \\
(0,9)\end{array}$ & Observations \\
\hline 1. & Slope & $\begin{array}{l}\geq 0 \% \\
\text { and } \\
\leq 25 \%\end{array}$ & $\begin{array}{l}\text { Potato, wheat, } \\
\text { vegetables, lucerne, } \\
\text { peas, barley, maize, } \\
\text { clover }\end{array}$ & - & 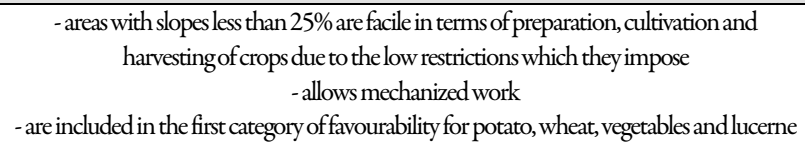 \\
\hline 2. & Altitude & $\leq 750 \mathrm{~m}$ & $\begin{array}{l}\text { Wheat, vegetables, } \\
\text { lucerne, peas, barley }\end{array}$ & $\begin{array}{l}\text { Maize, potato, } \\
\text { clover }\end{array}$ & $\begin{array}{l}\text {-in correlation with rainfall and temperature, areas found bellow } 750 \text { m altitude are the } \\
\text { most suitable for crops } \\
\text { - wheat, lucerne, peas and barley are included in the first category for favourability, while } \\
\text { maize, potato and clover in class number } 2 \text { for favourability }\end{array}$ \\
\hline 3. & Orientation & $\begin{array}{l}\text { N,NW,NE.... } \\
\quad \geq-1 \text { and } \\
\quad \leq 360\end{array}$ & $\begin{array}{r}\text { Potato, wheat, veget } \\
\text { barley, ma }\end{array}$ & $\begin{array}{l}\text { les, lucerne, peas, } \\
\text {, clover }\end{array}$ & $\begin{array}{l}\text { - give to the territory suitability according to the which use is carried out analysis } \\
\text { - all types of orientations are suitable for agricultural use because agricultural crops can be } \\
\text { independent from some orientations, depending on their specific } \\
\text {-the type of orientations analysed for each parameter emphasize the good and very good } \\
\text { suitability for potato, wheat, vegetables, lucerne, peas, barley, maize and clover }\end{array}$ \\
\hline 4. & $\begin{array}{l}\text { Fragmentati } \\
\text { on depth }\end{array}$ & $\leq 150$ & $\begin{array}{l}\text { Wheat, vegetable, } \\
\text { peas, barley, maize }\end{array}$ & $\begin{array}{l}\text { Potato, lucerne, } \\
\text { clover }\end{array}$ & $\begin{array}{l}\text { - land area with high altitudinal difference impose restrictiveness regarding facilitated } \\
\text { preparatory work, culture, maintenance and harvesting of mechanized production system } \\
\text { - are identified cultures from the first class for wheat, vegetables, barley, on surfaces with } \\
\text { low horizontal fragmentation (under } 50 \mathrm{~m} \text { ), territories identified with less high surfaces } \\
\text { - potato, lucerne and clover crops are identified on surfaces that have a fragmentation } \\
\text { depth between } 50-150 \mathrm{~m} \text {, spatially grafted on submountain and mountain units with low } \\
\text { temperatures and large amount of rainfall, which give favourability for the mentioned } \\
\text { crops }\end{array}$ \\
\hline 5. & $\begin{array}{c}\text { Fragmentati } \\
\text { on density }\end{array}$ & $\leq 2$ & $\begin{array}{r}\text { Potato, wheat, veget } \\
\text { barley, ma }\end{array}$ & $\begin{array}{l}\text { les, lucerne, peas, } \\
\text {, clover }\end{array}$ & $\begin{array}{c}\text { - low density of relief fragmentation highlights large areas with homogeneous surfaces used } \\
\text { for agricultural crops } \\
\text {-low fragmentation of territory reveals the continuity of parcels and the possibility of } \\
\text { workingin mechanized system } \\
\text { - high fragmentation give the major restrictiveness regarding the continuity of parcels and } \\
\text { spatial expending of them }\end{array}$ \\
\hline 6. & $\begin{array}{l}\text { Annual } \\
\text { average } \\
\text { temperature } \\
\left({ }^{\circ} \text { Celsius }\right)\end{array}$ & $\geq 6.1$ and $\leq 9.6$ & $\begin{array}{l}\text { Potato, clover, } \\
\text { vegetables, barley, } \\
\text { peas, beans }\end{array}$ & $\begin{array}{l}\text { Barley, maize, } \\
\text { potato, clover }\end{array}$ & $\begin{array}{c}\text {-is a restrictive parameter } \\
\text {-limits the period of commencement of agricultural operations, growing, ripening and } \\
\text { harvesting } \\
\text { - potato, clover, vegetables, barley, peas and beans fit in the first favourability class for } \\
\text { temperatures between } 6 \text { and } 9.6 \text { degree, situated in lower areas of low hills } \\
\text { - barley, maize, potato and clover fit in second favourability class, towards the lower limit of } \\
\text { temperature }\end{array}$ \\
\hline 7. & $\begin{array}{l}\text { Annual } \\
\text { average } \\
\text { rainfall } \\
(\mathrm{mm})\end{array}$ & $\geq 596$ and $\leq 769$ & $\begin{array}{l}\text { Potato, clover, } \\
\text { vegetables }\end{array}$ & $\begin{array}{l}\text { Barley, wheat, } \\
\text { maize, lucerne, } \\
\text { potato }\end{array}$ & $\begin{array}{l}\text {-is a restrictive parameter } \\
\text { - they are closely correlated with the disposition of the relief altitude intervals } \\
\text { - heavy rainfall specific to high altitudes are less favourable for clover and vegetable crops, } \\
\text { fittingin the middle category in terms of favourability } \\
\text { - lower amount of rainfall, that fit, in term of favourability, for the submedium category, } \\
\text { the correlation with relatively average temperatures to lower temperatures reveal areas } \\
\text { suitable for barley, wheat, maize and lucerne crops }\end{array}$ \\
\hline 8. & Landslides & $\geq-9.5$ and $\leq 0.3$ & Lucerne, clover & $\begin{array}{l}\text { Potato, wheat, } \\
\text { vegetables, barley, } \\
\text { maize }\end{array}$ & $\begin{array}{l}\text {-is a restrictive parameter } \\
\text { - lucerne and clover, included in the first category for favourability (category one), havea } \\
\text { role of stabilization and reduction of the erosion effect, being considered as pioneer } \\
\text { agricultural crops for landslides }\end{array}$ \\
\hline 9. & Flooding & $=0$ & $\begin{array}{r}\text { Lucerne, clover, pota } \\
\text { barley, }\end{array}$ & $\begin{array}{l}\text { wheat, vegetables, } \\
\text { aaize }\end{array}$ & $\begin{array}{l}\text { - is a restrictive parameter } \\
\text { - the lack of flooding areas reveals their favourability } \\
\text { - flooding areas emphasize the retroactivity for all crops }\end{array}$ \\
\hline
\end{tabular}

The final step was to finalize and implement spatial analysis equation, equation that integrated all database structures and identifiers of spatial analysis defined in previous stage, with the main purpose of illustrating the suitable areas in terms of crops.

Due to specific values of suitability for each parameter, a spatial analysis equation was defined, each parameter having equal proportion in the final result. Using the function "Raster Calculator" of a geoinformatic program, the following equation was obtained:

("Average annual temperature" $>=6.1$ ) \& ("Average annual temperature" < = 9.6) \& ("Average annual rainfall" > = 596) \& ("Average annual rainfall" <= 769) \& ("slope" $<=25$ ) \& ("flooding" ==0) \& ("Landslide Probability" >= - 9.5) \&
("Landslide Probability" <=0.3) \& ("Altitudinal scale $(m)$ " <= 750) \& ("Relief energy"<=150) \& ("Fragmentation density" <= 2)

Where: Average annual temperature, ... etc. - input parameter in the equation

$$
\begin{aligned}
& \mho \text { - logical identifier } \\
& >=,<==\text { - mathematic identifier } \\
& 6.1,596 \ldots \text {...etc. - coefficients of parameters }
\end{aligned}
$$

The equation result (Fig. 11) was materialized in a database raster with numeric attributes 0 ("False", all surfaces that do not meet conditions) and 1 ("True", all areas that meet conditions) (Bilaşco et al., 2013), in this case surfaces with zero suitability for agricultural crops and land suitable for them. 


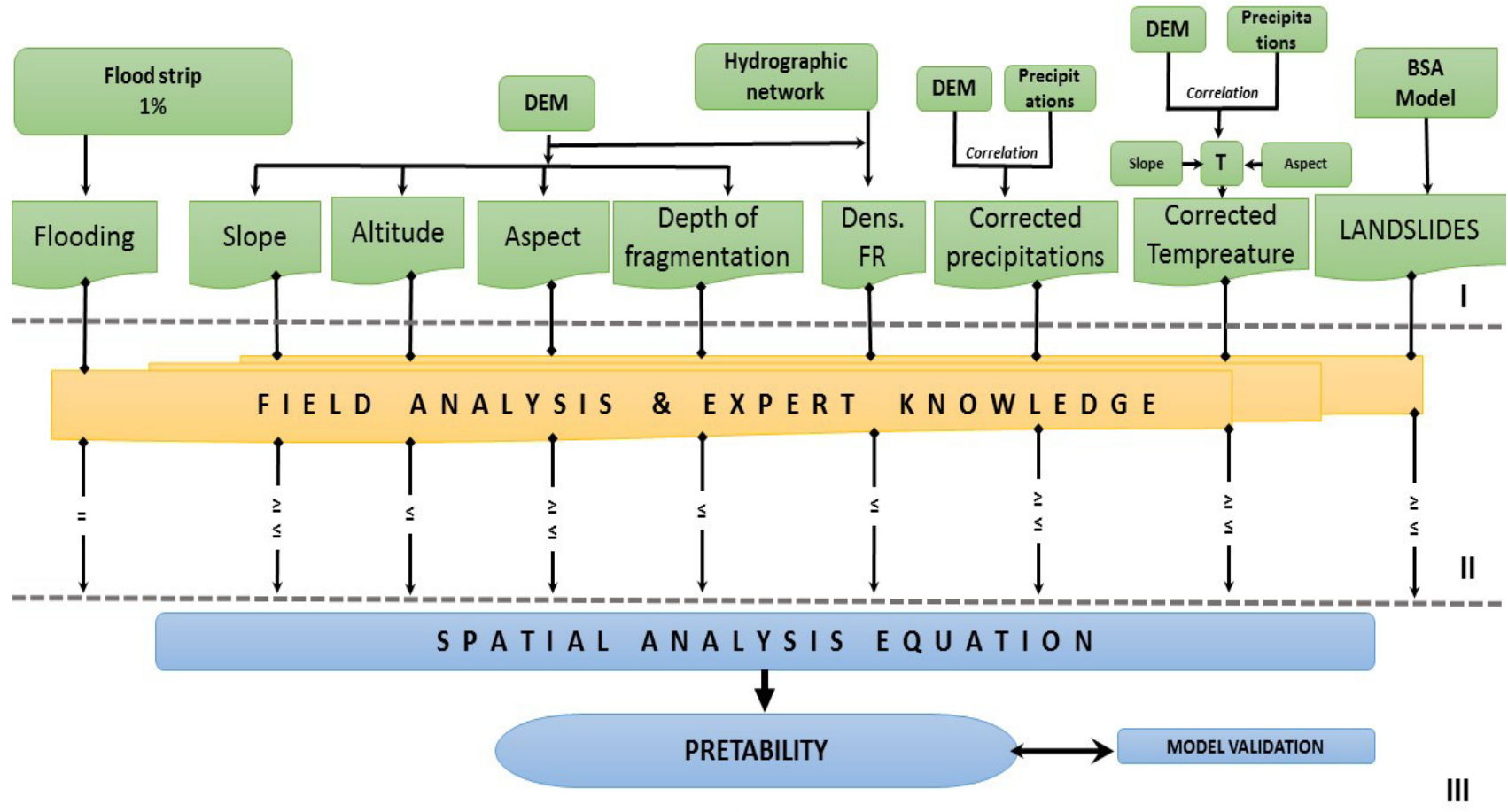

Fig. 11. Conceptual scheme of applied model

\section{Results}

Analysis of the obtained database after finalizing the model of spatial analysis, highlights the low extension of areas suitable for crops (\%). Suitable areas have territorial extension mainly in Mures, corridor, some lower plateaus and the meadows.

Based on administrative units, the following ones stands out: Gârda de Jos, Alba Iulia and Sebeş, which offers high suitability for agricultural crops on areas larger then $18-20 \mathrm{~km}^{2}$, which correspond to the proportion of over $20 \%$ from the surface of these units. The largest areas with restrictiveness for crops, due to the influence of parameters that are negatively influencing land cultivation and maintenance are: Metes (99\% of the territory), Sântimbru (93\%) and Ighiu (87\% of its adjacent area) (Table 12).

Model validation was performed using the method of comparison between the final result with the results achieved by the traditional method, the land evaluation mark for wheat and vegetable crops. This kind of validation of the results obtained by applying a model based on expert knowledge with the reality on the ground, gives an insight into the predictability of results
(Chung and Fabbri, 2008). To achieve validation, two surfaces were randomly selected and the results were compared with those areas considered suitable for respective crops. The first area as a test area is located South of the village Gâlda de Jos and the second one is West of the village Şard. After comparing the four results (Fig. 13), stands out the heavily overlapping modelled areas, considered suitable with favourable surfaces for crops, in this case wheat, which indicates the accuracy of the outcome.

\section{Discussions}

Morphometric and risk parameters represent the major factors of restrictiveness or favourability regarding the identification of suitable land for agricultural crops due to their complexity as way of manifestation and influence in landscape (Halder, 2013).

Individual analysis of the factors presented in this report highlights not only the complexity of the morphometric and risk parameters that were analysed, but also the major influence that each and every one of them has on

Table 12. Classification of administrative territorial units on suitability classes

\begin{tabular}{|c|c|c|c|c|c|}
\hline \multirow{2}{*}{ Nr. } & \multirow{2}{*}{ Administrative territorial areas } & \multicolumn{2}{|c|}{ Non suitable areas } & \multicolumn{2}{|c|}{ Suitable areas } \\
\hline & & $\mathrm{km}^{2}$ & $\%$ & $\mathrm{~km}^{2}$ & $\%$ \\
\hline 1 & Galda de Jos & 68.43 & 71.71 & 26.99 & 28.29 \\
\hline 2 & Teius & 35.32 & 84.61 & 6.42 & 15.39 \\
\hline 3 & Cricau & 41.46 & 83.60 & 8.14 & 16.40 \\
\hline 4 & Ighiu & 105.43 & 87.06 & 15.66 & 12.94 \\
\hline 5 & Metes & 137.16 & 99.77 & 0.31 & 0.23 \\
\hline 6 & Santimbru & 39.23 & 93.74 & 2.62 & 6.26 \\
\hline 7 & Alba Iulia & 73.15 & 75.29 & 24.01 & 24.71 \\
\hline 8 & Berghin & 60.28 & 84.97 & 10.66 & 15.03 \\
\hline 9 & Ciugud & 36.00 & 86.77 & 5.49 & 13.23 \\
\hline 10 & Vințu de Jos & 65.72 & 78.01 & 18.53 & 21.99 \\
\hline 11 & Sebeş & 79.61 & 75.01 & 26.52 & 24.99 \\
\hline
\end{tabular}




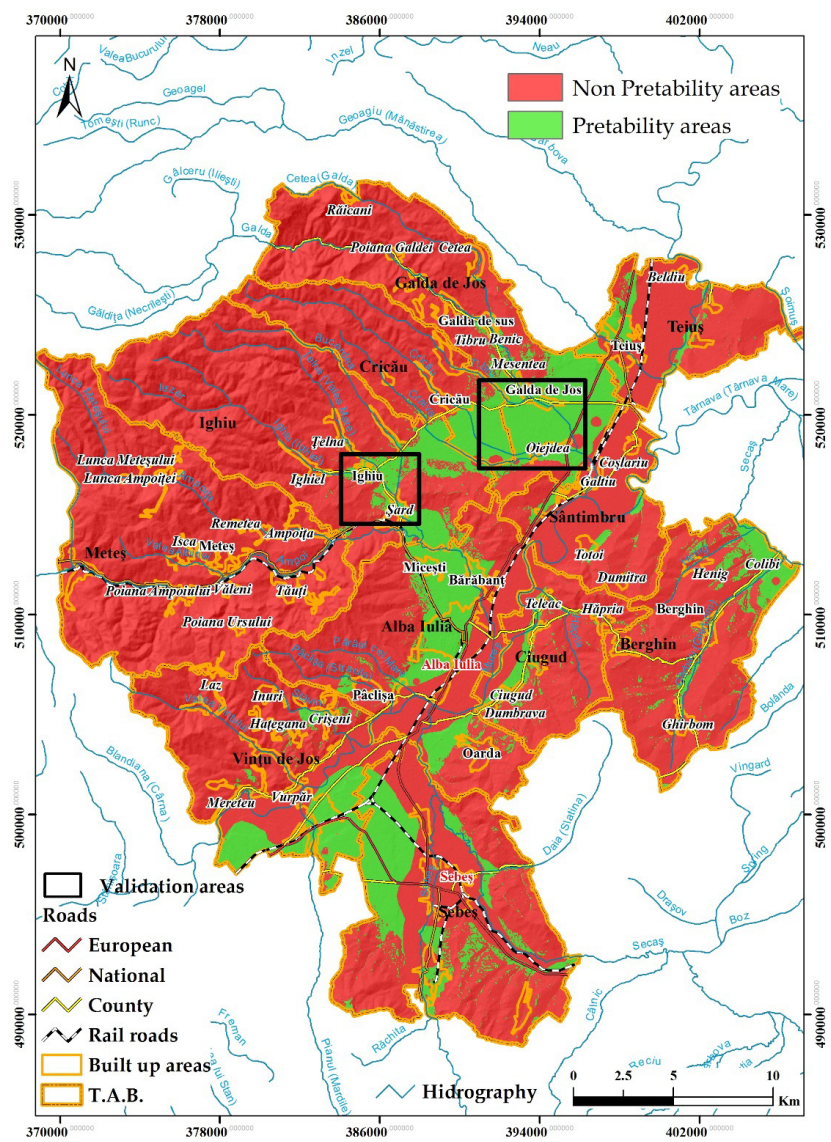

Fig. 12. Suitability map for agricultural crops

establishing and delimiting surfaces suitable for agricultural crops (Bhandari et al., 2013). Thus, noticing the altitude zoning for respective crops and their correlation with vertical natural setting of the temperature (suitability of agricultural crops on surfaces with temperatures relatively medium and low altitudes), it lead to identifying suitable areas in Mureş corridor, sub-mountain hills and lowland areas. Rainfall, as a defining parameter in determining suitability, exerts its influence on relief surfaces characterized by high altitudes and low temperatures with average slopes, which only highlights suitability for specific and acclimatized crops (potato, clover etc.). The analysis of rainfall as suitability parameter cannot be made only closely related to groundwater, which in areas of Mureş corridor it is close to the surface and compensates the supply of precipitation water, favouring thus the suitability of areas for agricultural land.

Risk-inducing elements, landslides and flooding due to territorial expansion of areas with different areas of vulnerability (average and high vulnerability to very high for landslides and areas for flooding) are major limiting factors in terms of suitability in identifying agricultural areas (Borrelli et al., 2014; Göransson et al., 2014; Kundzewicz et al., 2014). The areas identified as flood plains induce restrictiveness for $100 \%$ regarding suitability, and areas identified as vulnerable areas, from average-high to very high, for landslides induce partial restrictiveness, depending on the degree of vulnerability.

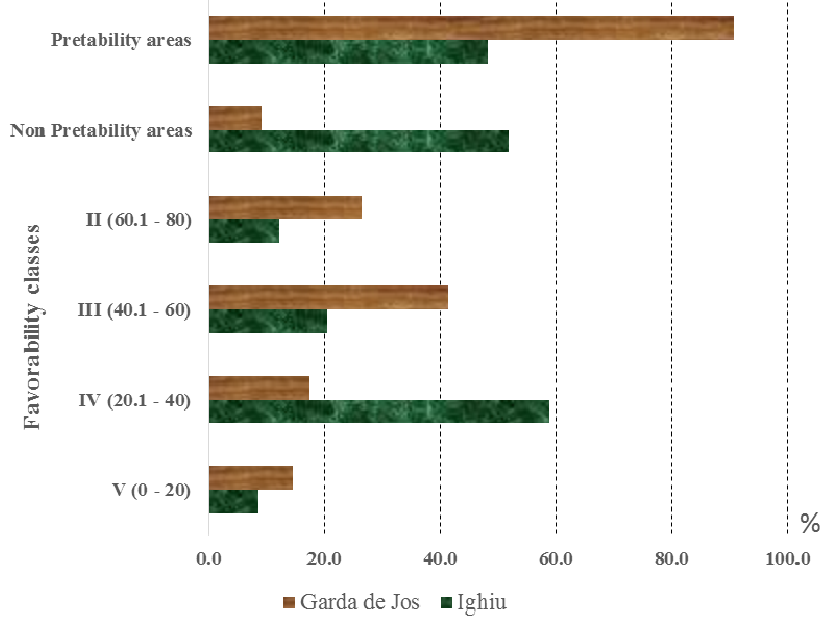

Fig. 13. Comparative analysis of suitability classes and the correspondence of suitability classes for crops

The spatial analysis model proposed in the present study was structured on three main stages: first stage represented the correct definition and implementation of databases with different structures (vector, raster) and ways of obtaining (derivation, modelling) intermediate and final results with a high degree of accuracy and territorial validation; the second stage was represented by the analysis of databases based on field study, bibliographic information and expert knowledge, aimed mainly to identify the logic and mathematic used in the equation of spatial analysis; the third stage represented the base of spatial equation model, by means of two main steps (spatial analysis equation and validation) (Roşca et al., 2015).

Integrated analysis of all parameters considered for the identification of the agricultural land suitability was achieved by incorporating into the spatial analysis equation the quantitative values of variation of the suitability through the logical and mathematical identifiers established based on the quantifiable information obtained in the analysis from the second stage. By applying the spatial analysis equation on specific databases, the spatial extension of territories was obtained for areas suitable for agricultural crops. The model of spatial analysis cannot be applied as long as the result validation step is not completed (Van Diepen et al., 1991). The authors validated the model by comparing the results with the favourability of a crop, wheat respectively, randomly selected, on two indiscriminately selected areas, the result being one included in the very good category, with a validation rate of $88.9 \%$ at comparing areas and $90.8 \%$ in comparing as regards to the spatial extension surface of the administrative unit.

\section{Conclusions}

The integration of the results of the analysis of individual parameters of a conceptual model, integrated into a model of GIS spatial analysis, complex in terms of techniques and methods of achieving, makes identifying areas suitable for agricultural land a necessity, given the current trend regarding the integrated land management. The proposed model can represent a preliminary stage of the land evaluation mark for establishing suitability. Tightening the territorial areas of surfaces suitable for some 
312

general type of use would make the time for land evaluation mark shorter. The identification model of suitable agricultural crops proposed in the current study can be applied to almost all surfaces of meadow, hill and mountain areas with low altitudes because the quantitative and quantifiable values extracted for each parameter, presented in this study and included in the spatial analysis equation, fall into the range of values used within the current methodologies of land evaluation mark suitability.

\section{References}

Bătinaş R, Bilaşco Ş (2009). The use of GIS techniques in estimating the floodable stripes in relation with discharges value with low probabilities of occurrence. Case study: River Arieş - Turda City.Studia Universitatis Babeş-Bolyai, GeographiaLIV 3:195-202.

Bhandari S, Jhadav ST, Kumar S (2013). Land capability classification and crop suitability assessment in a watershed using RSandGIS - a case study of watershed in Dehradun, Uttarakhand. SSARSC International Journal of Geo Science and Geo Informatic 1(1):1-15.

Bilașco Ș (2010). GIS model for achieving the spatial correlation between average multi-annual precipitations and altitude. Studia Universitatis Babes-Bolyai, GeographiaLIV2:71-78.

Bilaşco Ş, Cocean P, Nicula G, Drăgan M (2013). Morphometric limitations to spatial planning in the Arieş Basin (in Romanian). Geographia Napocensis VII/1:21-35.

Borrelli P, Märker M, Panagos P, Schütt B (2014). Modeling soil erosion and river sediment yield for an intermountain drainage basin of the Central Apennines, Italy. Catena 114:45-58.

Cernescu N (19641994). Romanian soil, map scale 1:200.000 (in Romanian). Institutul Geologic - Institutul de Cercetari pentru Pedologie si Agrochimie, Bucuresti.

Chung CJ, Fabbri AG (2008). Predicting landslides for risk analysis - spatial models tested by a cross-validation technique. Geomorphology 94:438452.

Dumitru S, Mocanu V, Ignat P, Gherghina A, Seleceanu I (2010). Land evaluation at farm level using gis techniques. Analele Universitătiii din Craiova, seria Agricultură, Montanologie, Cadastru 368-373.

FAO (1983). Guidelines: Land evaluation for rainfed agriculture. FAO, Rome, Italy. Soils Bull 52:11-54.

Florea N, Bălăceanu V, Răuță C, Canarache A (1986). Development methodology of soil studies - part I and part II. Institutul de Cercetări pentru Pedologieşi Agrochimie.

Göransson G, Norrman J, Larson M, Alén C, Rosén L (2014). A methodology for estimating risks associated with landslides of contaminated soil into rivers. Science of the Total Environment 472:481-495.

Halder JC (2013). Land suitability assessment for crop cultivation by using remote sensing and GIS. Journal of Geography and Geology 5(3):65-74.

Kundzewicz ZW, Kanae S, Seneviratne SI, Handmer J, Nicholls N, ... Sherstyukov B (2014). Flood risk and climate change: Global and regional perspectives. Hydrological Sciences Journal 59(1):1-28.
Moțoc M (1983). The average rate of erosion of soil degradation in RS. Romania (in Romanian). Buletinul Informativ ASAS, no 13, ASAS Bucureşti.

Munteanu I, Dumitru S, Mocanu V, Moise I (2000). The types of land in Romania, scale 1:2,500,000 after SOTER methodology and their use to substantiate the strategy of conservation and protection of the land (in Romanian). Lucrările Simpozionului "Protecția Mediului în Agricultură” Bucureşti 1:102-111.

Păcurar I, Buta M (2007). Soil and agricultural land evaluation marks (in Romanian).EdAcademicPres Cluj-Napoca.

Petrea D, Bilaşco Şt, Roşca S, Vescan I, Fodorean I (2014). The determination of the landslide occurence probability by spatial analysis of the land morphometric characteristics (case study: the Transylvanian Plateau). Carpathian Journal of Earth and Environmental Sciences 9:91-110.

Posea Gr, Badea L (1984). Romania - relief units and geomorphological regionalization (in Romanian). Ed Științificăși Enciclopedică, Bucureşti.

Roșca S (2014). Application of soil loss scenarios using the ROMSEM model depending on maximum land use pretability classes. A case study. StudiaUBB GeographiaLIX:101-116.

Roşca S, Bilasco Ş, Pacurar I, Oncu M, Negrusier C, Petrea D (2015b).Land capability classification for crop and fruit product assessment using GIS technology. Case study: the Niraj River Basin (Transylvania Depression, Romania). Notulae Botanicae Horti Agrobotanici Cluj-Napoca 43(1):235-242.

Roșca S, Bilașco Ș, Petrea D, Vescan I, Fodorean I, Filip S (2015). Application of landslide hazard scenarios at annual scale in the Niraj River basin (Transylvania Depression, Romania). Natural Hazard 77(3):15731592.

Roșca S, Petrea D, Bilaşco Ş, Rus I, Irimuş I-A, Fodorean I, Vescan I (2014). Assessment of flood hazard and risk using GIS and historical data. Case study: the Niraj River Basin (Transylvania Depression, Romania). Informatics, Geoinformatics and Remote Sensing. Conference Proceedings - Photogrammetry and Remote Sensing, Cartography and GIS Vol III:497-504.

Țârău D (2003).The theoretical and practical assessment of credit worthiness and land from an ecological perspective (in Romanian). Ed Solness, Timișoara.

Teaci D (1989). Modern concepts for defining and determining the productive capacity of agricultural land through modelling mathematics and mathematical heuristics (in Romanian). Lucrări Stiințifice SNRSS Românianr.26B.

Teaci D, Popescu I (1972). Zoning farmland soil and climate of the RS. Romania, scale 1:500,000. ICPA Bucureşti62 pages, 4 files.

Van Diepen CA, Van Keulen H, Wolf J, Berkhout JAA (1991). Land evaluation: from intuition to quantification. In: Stewart BA (Ed). Advances in Soil Science. Springer, New Yorkpp 139-204. 